\title{
Spiritual Well-Being of Senior High School Students in Philippine Public Schools
}

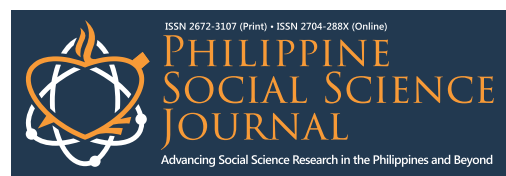

Joehally B. Cena ${ }^{1}$ and Joel M. Bual ${ }^{2}$

${ }^{1}$ Sum-ag National High School, Bacolod City, Philippines

${ }^{2}$ Pandan Bay Institute, Antique, Philippines

\begin{tabular}{l} 
Article history: \\
Submitted: 16 November 2021 \\
Revised: 11 December 2021 \\
Accepted: 21 December 2021 \\
\hline \\
Keywords: \\
Social science \\
Spiritual well-being \\
Senior high school students \\
Descriptive-comparative \\
Philippines
\end{tabular}

1.0. Introduction

Spirituality is essential in the lives of young adults in the development of their autonomy, resilience, and responsibility (Kim \& Esquivel, 2011). This core human component gives the driving energy for a person's search for security, meaning, satisfaction in life, and a sense of belief (Rovers \& Kocum, 2010). Moreover, it also helps form the values that will lead them to the holistic improvement of their well-being (Nazam \& Husain, 2016). With their spirituality intact, their disposition and behavior towards life are also in place, encouraging them to participate actively in the church and society (Chirico, 2016). Thus, the development of young adults' spiritual well-being is necessary (Shek, 2012).

Correspondingly, the schools are the best institutions in developing the spiritual well-being of the learners as young adults (Aguas, 2019). They are fitting institutions to hone these students since values education is incorporated among the curricular subjects (Mata-McMahon, 2016). When values are taught among these students, their spiritual aspect is also positively affected (Kotaiah, 2014). Thus, values formation among schools is necessary and should be strengthened to guarantee the formation and development of the learners' spiritual well-being (Johnson, 2001). However, Philippine public schools may have values education subjects but minimally focus on spiritual formations, unlike in Catholic schools (Bual \& Madrigal, 2018). Aside from this, most learners nowadays are compromised by the secularistic, modernistic, and materialistic mindsets, which depreciate their values and spiritual dispositions (Banusing \& Bual, 2021; Madrigal \& Oracion, 2018).

Fortunately, in terms of the curricular subjects in public schools, some senior high school students have religion-related subjects like "Introduction to World Religions and Belief Systems". This subject introduces them to the importance of religion and spirituality in their lives as students and as persons (Department of Education [DepEd], 2016). Corollary to the previous observations, young people view specific issues in life as not simply a deterioration in the morality and increasing religiosity of students. Nevertheless, it is also an outcome of their being decisive and observant of what they think, believe, and apply in real life in dealing with the changes around them specific to society and culture (Cornelio, 2011). Not to mention, these phenomena are even heightened by the pandemic circumstance where students have limited opportunities to attend faith-related celebrations, which affect their spiritual well-being (Dein et al., 2020).

There were studies conducted on spiritual well-being in the Philippines: Among diocesan seminarians of Antique (Legada et al., 2020), among senior high school students in a Philippine

This article published by Philippine Social Science Journal (PSSJ) is licensed under a Creative Commons AttributionNoncommercial 4.0 International (CC BY-NC 4.0). You are free to share (copy and redistribute the material in any medium or format) and adapt (remix, transform, and build upon the material). Under the following terms, you must give appropriate credit, provide a link to the license, and indicate if changes were made. You may do so in any reasonable manner, but not in any way that suggests the licensor endorses you or your use. You may not use the material for commercial purposes. 
Catholic college (Madrigal et al., 2020), an exploratory study among youth in the Philippines and Vietnam (Pham \& Del Castillo, 2020), and among faculty members in Philippine Christian colleges and universities (Oberholster et al., 2000). These studies have established the spiritual well-being of Filipino students. Though Filipino youth's spiritual well-being has been subjected to test due to life's demands and challenges, it continues to grow and survive due to the support of institutions and the environment that provide venues for public ritual and private reflections (Lituañas, 2007). But little has been said about the spiritual, religious, and existential well-being of senior high school students, especially among public secondary schools. This is the research gap which this study would like to fill in.

Thus, this study assessed the degree of the spiritual well-being of senior high school students of public schools in Bacolod City, Philippines, during 2020-2021 in the areas of religious and existential well-being when they are taken as a whole and grouped according to sex, grade level, family income, and religious orientation. Likewise, it also compared the students' assessments on spiritual, religious, and existential well-being when grouped according to the demographics. Lastly, the findings of this study may serve as basis in the continuous improvement of public schools particularly in terms of strengthening their values and religious formations vis-à-vis the students' holistic growth and development.

\subsection{Framework of the Study}

The study theorized that the spiritual well-being of students is deeply rooted in the connection of their religious and existential well-being. Also, it is perceived that this religious and existential wellbeing varies according to their demographics. This is anchored in the Spiritual Well-Being Theory of Paloutzian and Ellison (1979). This theory perceives spiritual well-being as a "personality attribute conceived of having one vertical dimension connoting one's perception of a relationship to God, and one horizontal dimension connoting one's perception of life's meaning, purpose or satisfaction with one's existence."

Correspondingly, it has two dimensions: vertical (religious) and horizontal (existential). The religious dimension refers to the sense of well-being in terms of man's relationship with God or higher power. On the other hand, the existential dimension attributes to a man's sense of purpose in life, peace, and fulfillment (Paloutzian \& Ellison, 1982). This core reveals that spiritual well-being is the expression of life connected with God, self, community, and environment (Paloutzian \& Ellison, 1979). These two elements of spiritual well-being, which are religious and existential, combine, communicate, and overlap with each other and draw a feeling of spiritual health, satisfaction, and purpose in life. Also, this assumption of spiritual well-being can be linked to one's spiritual activities, directly related to one's vertical connection with God. It modifies one's horizontal perspective, making healthy decisions and discernment. With high spiritual well-being, the individual can transform negative occurrences into positive ones. Eventually, one can also transform challenges towards a more fulfilling life with meaning (Paloutzian \& Ellison, 1979).

In the context of public-school students, their spiritual well-being also varies according to their orientations and profile. Some may not be into spirituality due to family, religious backgrounds, and socioeconomic needs (Taliaferro, 2009). Some may also be into the spiritual aspects due to the consistent formations at home and schools (Alicea \& Edwin, 2014). In other words, their spiritual well-being is acquired depending on their type of formations and background. The above theory is most significant in determining the degree of the spiritual well-being of senior high school students of public schools in Bacolod City in the areas of religious well-being and existential well-being.

\subsection{Methods}

Utilizing a quantitative research design, this study used the descriptive-comparative approach. The approach was utilized to measure the degree of the spiritual well-being of students and compared their assessments when grouped according to sex, grade level, family income, and religious orientation. The respondents were the 335 senior high school Humanities and Social Sciences (HUMSS) students of public schools in Bacolod City, Philippines, which were determined through stratified sampling. In assessing the study, the 20-item standardized Spiritual Well-Being Questionnaire by Paloutzian and Ellison (1982) in the areas of religious and existential well-being was employed using the scale: 1-low, 2-moderate, and 3-high. 
The data analysis was done using mean and standard deviation to measure the degree of the spiritual well-being of students. Meanwhile, using the Kolmogorov-Smirnov, the normality test results revealed that spiritual well-being $[K S=0.131, p=0.000]$, religious well-being $[K S=0.069, p=0.001]$, and existential well-being [KS $=0.067, p=0.001]$ are not normally distributed. Hence, the Mann-Whitney $\mathrm{U}$ Test was justified in comparing the differences in the spiritual, religious, and existential well-being assessments of the students when grouped according to the demographics. Lastly, in ensuring the ethical soundness of the study, the principles of respect for persons, beneficence, and justice were established, especially on privacy, confidentiality, and potential risks.

\subsection{Results and Discussion}

\section{Degree of the Spiritual Well-Being of Senior High School Students}

Table 1 presents the degree of the spiritual well-being of senior high school students of public schools in Bacolod City, Philippines. As a whole, the degree of spiritual well-being $(M=99.08$, $S D=13.71)$ is moderate. The domain of religious well-being $(M=51.95, S D=7.17)$ was rated high, while the existential well-being $(M=47.14, S D=7.55)$ was rated moderate.

Generally, the moderate rating indicates that the students of the public schools in Bacolod City, Philippines have an average inclination towards their purpose, satisfaction in life, faith and relationship in God (Rovers \& Kocum, 2010). Subsequently, their overall spiritual well-being result failed to establish among students the link or connection between their religiosity and their search for recognition of meaning and contentment (Mak et al., 2011). This would mean that the positive relationship with God does not resemble their sense of purpose in life (Madrigal et al., 2020).

With the disconnection of the dimensions, it signifies a need for rigorous improvement in strengthening the religious and values formations among public schools to guarantee the link and the spiritual well-being of their students. Accordingly, when the formations are intact, these students continuously grow and develop, realizing the essentials of their faith in God, which will direct them to recognize values in their search for clear purpose and satisfaction (Schippers \& Ziegler, 2019). In support, Jomuad et al. (2021) perceive that when values formations are effectively advanced among schools, the students acquire the holistic growth and development that surely helps them succeed in life with clear direction.

Meanwhile, the overall moderate spiritual well-being result is attributed to the unsustainable religious formation among public schools where spiritual aspects of formation are generally not given attention, unlike in Catholic schools (Bual \& Madrigal, 2018; Spesia, 2016; Banusing \& Bual, 2020). Public schools may have religious activities but are limited to attending monthly masses, catechetical instructions, retreats, and recollections, which are not enough to form the students' spirituality (Woodward, 2020). Additionally, the result is also ascribed to values formation issues among public schools. Not to mention, the challenge of integrating values in the curricular subjects and the teachers' expertise which is not aligned with values education as supported by Thornberg

Table 1. Degree of the spiritual well-being

\begin{tabular}{lccc}
\hline \multicolumn{1}{c}{ Variables } & M & SD & Int \\
\hline Sex & & & \\
$\quad$ Male & 97.30 & 14.34 & $\mathrm{Mo}$ \\
$\quad$ Female & 100.13 & 13.25 & $\mathrm{Hi}$ \\
$\quad$ Grade Level & & & \\
$\quad$ Grade 11 & 98.92 & 13.43 & $\mathrm{Mo}$ \\
$\quad$ Grade 12 & 99.31 & 14.15 & $\mathrm{Mo}$ \\
$\quad \begin{array}{l}\text { Family Income } \\
\quad \text { Low-income class }\end{array}$ & 98.70 & 13.81 & $\mathrm{Mo}$ \\
$\quad$ High-income class & 100.15 & 13.45 & $\mathrm{Hi}$ \\
$\quad$ Religious Orientation & & & \\
$\quad$ Catholic & 98.79 & 13.95 & $\mathrm{Mo}$ \\
$\quad$ Non-Catholic & 99.84 & 13.12 & Mo \\
$\quad$ Whole & 99.08 & 13.71 & Mo \\
\hline Note: Mo=Moderate, Hi=High & & &
\end{tabular}


(2008). Not to mention the pandemic circumstance which affected the students academically and spiritually (Dein et al., 2020).

Relatedly, the spiritual well-being result of this study is congruent with the findings of Legada et al. (2020) among the Catholic school senior high school students. This does not support Cohen-Zada and Sander (2006) that Catholic school students have a higher spiritual outlook in life than those in public schools given their faith and values formations. This could be ascribed to the students who either in Catholic or public schools are less participative in faith-related activities and disposition towards forming values. This is even heightened by the modernistic and secularistic mindsets of students nowadays (Bual \& Madrigal, 2018; Banusing \& Bual, 2020). However, further studies are encouraged in both contexts to confirm the previous studies. Acknowledging the study results, these signify the necessity for public schools to advance and strengthen their religious and values formations to guarantee the strong link of these two dimensions and the general spiritual well-being of their students (Madrigal et al., 2020).

\section{Religious Well-Being}

The religious dimension is perceived as a sense of well-being towards one's relationship with God (Moberg, 2002; Paloutzian \& Ellison, 1982). In Table 2, the high rating of this dimension indicates that the students of these public schools still believe in God. In return, this made them exhibit their religious beliefs and practices (Alorani \& Alradaydeh, 2018). The result could be attributed to the outnumbering Catholic students in terms of their religious orientation, which probably might have affected the high assessment of this dimension, as supported by Cornelio (2011). Elaborately, regardless of their public-school choice, their knowledge and belief in God are governed by their religious upbringing and church membership. In support, Scheper (2013) argues that those religiously affiliated students, regardless of what schools they belong to, remain associated with their faith. Not to mention, most of the students' parents are Catholics and devotees of faith, which might have influenced their children's religious upbringing and disposition (Oracion \& Madrigal, 2019).

Demographically, the findings on sex and family income of the students might also have a say in the result. Regarding sex, the female outnumbered male students, who might influence the assessment. Lippman and McIntosh (2010) claimed that female students are more religious and perceive greater faith than males. In support, Agoncillo (2015)'s findings revealed that female students found value in spirituality and are more committed to religious beliefs than males. Meanwhile, most of the students came from low-income families. However, Schieman (2010) found that though students chose public schools because of their low income, this does not mean that they are not devotees of faith. Despite the high assessment, the findings imply the need for public schools to improve and strengthen their faith-related activities to ensure a sustainable high religious well-being among students, which is of great help in recognition of values.

Table 2. Religious well-being

\begin{tabular}{lccc}
\hline Variables & $\mathrm{M}$ & $\mathrm{SD}$ & $\mathrm{Int}$ \\
\hline Sex & & & \\
$\quad$ Male & 50.90 & 7.65 & $\mathrm{Hi}$ \\
$\quad$ Female & 52.56 & 6.82 & $\mathrm{Hi}$ \\
$\quad$ Grade Level & & & $\mathrm{Hi}$ \\
$\quad$ Grade 11 & 51.88 & 7.05 & $\mathrm{Hi}$ \\
$\quad$ Grade 12 & 52.04 & 7.36 & $\mathrm{Hi}$ \\
$\quad$ Family Income & & & \\
$\quad$ Low-income class & 51.83 & 7.21 & $\mathrm{Hi}$ \\
$\quad$ High-income class & 52.28 & 7.09 & $\mathrm{Hi}$ \\
$\quad$ Religious Orientation & & & \\
$\quad$ Catholic & 51.85 & 7.29 & $\mathrm{Hi}$ \\
$\quad$ Non-Catholic & 52.18 & 6.88 & $\mathrm{Hi}$ \\
$\quad \begin{array}{l}\text { Whole } \\
\text { Note: Hi=High }\end{array}$ & 51.95 & 7.17 & $\mathrm{Hi}$ \\
\hline
\end{tabular}




\section{Existential Well-Being}

Existential well-being refers to one's sense of purpose, peace, and life satisfaction (Moberg, 2002; Paloutzian \& Ellison, 1982). With its moderate rating as shown in Table 3, this indicates that the students do not clearly recognize their purpose or meaning in life. Also, they do not have a clear view of a peaceful and satisfying life (Moberg, 2002). The assessment could be influenced by the level of the students' maturity in terms of existential aspects like recognizing one's purpose and life satisfaction (Dein et al., 2020). In support, the study of Kolzow (2014) found out that the maturity of most people to realize the essentials of having a clear vision, meaning, and contentment in life occur when they reach the point of having a job and life of their own.

Additionally, this could also be influenced by the threats brought about by the pandemic, which compromise their disposition in life (Dein et al., 2020). Accordingly, Ownsworth and Nash (2015) perceived that when people are faced with a vital threat in life, they ponder deeply upon existential concerns such as the meaning or purpose in life. In view of this, the pandemic threat negatively affected the students, which made them think of the uncertainties of their lives, which might influence the moderate assessment.

The moderate existential well-being result encourages the public schools to improve in their values education and formation by providing opportunities for students to develop their values towards life (Leijssen, 2014). However, one issue being faced by public schools is that the teachers' expertise is not aligned with the subject taught which compromises the formation (Thornberg, 2008). Further, values are mostly not integrated in the curricular subjects which is supposedly the potent opportunity to reinforce the students' disposition in life.

Aside from this, the issue of values could be ascribed to the kind of discipline and upbringing these students have at home, as supported by Thornberg (2008). It was found that when parents fail to provide adequate values formation to their children, these children will naturally bring that to school (Nazam \& Husain, 2016). Given the findings, these imply the need for public schools to ensure effective formation by exhausting ways to provide students with varied activities that elicit the integration, recognition, and development of values towards life (Lau, 2006). It also encourages hiring qualified and competent teachers to guarantee quality curricular integration and instruction (Bullough, 2011).

Table 3. Existential well-being

\begin{tabular}{lccc}
\hline Variables & $\mathrm{M}$ & SD & Int \\
\hline Sex & & & \\
$\quad$ Male & 46.40 & 7.72 & Mo \\
$\quad$ Female & 47.57 & 7.43 & Mo \\
$\quad$ Grade Level & & & \\
$\quad$ Grade 11 & 47.04 & 7.36 & Mo \\
$\quad$ Grade 12 & 47.28 & 7.84 & Mo \\
Family Income & & & \\
$\quad$ Low-income class & 46.87 & 7.63 & Mo \\
$\quad$ High-income class & 47.87 & 7.32 & Mo \\
Religious Orientation & & & \\
$\quad$ Catholic & 46.93 & 7.68 & Mo \\
$\quad$ Non-Catholic & 47.66 & 7.21 & Mo \\
$\quad$ Whole & 47.14 & 7.55 & Mo \\
\hline
\end{tabular}

Note: Mo=Moderate

\section{Difference in the Degree of Spiritual Well-Being}

Table 4 shows the difference in the degree of the spiritual well-being of senior high school students when grouped according to demographics. Utilizing Mann-Whitney $U$ Test, the findings showed no significant difference when grouped according to sex $[U=11654.000, p=0.095]$, grade level $[U=13242.500, p=0.688]$, family income $[U=10233.500, p=0.362]$, and religious orientation $[U=10862.000, p=0.559]$. Hence, the null hypothesis is accepted.

The absence of a significant difference in the result reveals that the demographics do not certainly affect senior high school's degree of spiritual well-being. This also shows that the students, regardless of their profile, share the same perceptions on spiritual well-being assessment (Wink \& Dillon, 2002). 
The rating could be ascribed to the students' less inclination on the religious aspects. Most of them want to go to school only without much attention on developing their spirituality. In other words, if they intend to develop their spiritual aspect, then they could have chosen Catholic schools. They do not mind whether they are spiritual or not. Some might also think that this assessment does not fit them and is appropriate only to the Catholic school setting. The result validates Gallagher and Newton (2009) that spiritual well-being mainly improves the person. It is also remarkable that the spiritual well-being encompasses the wholeness of the person where it is rooted in the fundamental and realistic dimension, which can be surmised through his personal experiences and encounters as supported by Lituañas (2007).

In terms of sex, the respondents do not differ on their spiritual well-being. This indicates that men's spirituality is closer with women despite the demographical outnumbering of the latter and those studies that favor female students (Murphy, 2016). Correspondingly, the result of the prevailing study contradicts the results of Madrigal and Oracion (2018) on the difference between spiritual wellbeing and sex. Meanwhile, Bryant et al. (2003) claimed that gender differences in spirituality might have been expected to exist. Women may have higher scores, but this does not indicate women's spirituality over men. In support, Poor et al. (2016) found that gender does not influence spiritual well-being. Further, Miller and Stark (2002) confirmed that it has no predictive role in spirituality.

Further, the spiritual well-being assessment of students does not also differ in terms of their grade level (Lippman \& McIntosh, 2010). The result could be ascribed to the same kind of religious and values formations experienced by the students across year levels in public schools as supported by Ene and Barna (2015). Similarly, the rating was consistent with the study of Mostafazadeh et al. (2012), where there was no significant difference in the spiritual well-being of students when grouped according to year level.

Relative to family income, Deb et al. (2016) argued that the students are spiritually inclined regardless of the income status of their families. Meanwhile, Krause et al. (2017) found that those with financial problems tend to be less involved in spiritual matters. This is because they are so engrossed with fulfilling their daily basic needs to survive.

On the one hand, the students share the same perception of spiritual well-being regarding their religious orientation. In support, King and Boyatzis (2015) found that every individual desire spiritual transcendence, contemplation, interconnectedness, and meaning in life despite their religious status. Meanwhile, Kloet and Galen (2011) recognized that once religious and non-religious individuals are distinguished in their beliefs, both share the same level of spiritual well-being.

Generally, the results conform with the findings of Wink and Dillon (2002), which argued that the growth and development of the students' spiritual well-being happen without reference to any demographic. Thus, the findings imply the need for these public schools to elevate in terms of providing their learners with the necessary religious and values formations inclusive of whatever demographic profiles of the students to ensure their spiritual well-being (Hook et al., 2015).

Table 4. Difference in the Degree of the Spiritual Well-Being according to Demographics

\begin{tabular}{|c|c|c|c|c|c|}
\hline \multirow{2}{*}{ Variable } & \multicolumn{2}{|c|}{ Sex } & \multirow[t]{2}{*}{$\mathrm{U}$} & \multirow[t]{2}{*}{$\mathrm{z}$} & \multirow[t]{2}{*}{$\mathrm{p}$} \\
\hline & Male & Female & & & \\
\hline \multirow{14}{*}{ Spiritual Well-Being } & 97.30 & 100.13 & 11654.000 & -1.669 & 0.095 \\
\hline & $(14.34)$ & $(13.25)$ & & & \\
\hline & \multicolumn{2}{|c|}{ Grade Level } & $\mathrm{U}$ & $z$ & $\mathrm{p}$ \\
\hline & Grade 11 & Grade 12 & & & \\
\hline & 98.92 & 99.31 & 13242.500 & -0.402 & 0.688 \\
\hline & $(13.43)$ & $(14.15)$ & & & \\
\hline & \multicolumn{2}{|c|}{ Family Income } & $\mathrm{U}$ & $z$ & $\mathrm{p}$ \\
\hline & Low-income class & High-income class & & & \\
\hline & 98.70 & 100.15 & 10233.500 & -0.912 & 0.362 \\
\hline & $(13.81)$ & (13.45) & & & \\
\hline & \multicolumn{2}{|c|}{ Religious Orientation } & $\mathrm{U}$ & $z$ & $\mathrm{p}$ \\
\hline & Catholic & Non-Catholic & & & \\
\hline & 98.79 & 99.84 & 10862.000 & -0.584 & 0.559 \\
\hline & $(13.95)$ & (13.12) & & & \\
\hline
\end{tabular}

Note: the difference is significant when $\mathrm{p} \leq 0.05$ 


\section{Difference in the Degree of the Spiritual Well-Being in terms of Religious Well-being}

Table 5 presents the difference in the degree of spiritual well-being in terms of religious wellbeing of senior high school students when grouped according to demographics. Using Mann-Whitney $U$ Test, the results showed no significant difference when grouped according to sex $[U=11556.000$, $p=0.073]$, grade level $[U=13192.500, p=0.645]$, family income $[U=10499.000, p=0.565]$, and religious orientation $[\mathrm{U}=11181.000, p=0.854]$. Hence, the null hypothesis is accepted.

The no difference result points out that the demographics of students do not affect their spiritual well-being in terms of their religious well-being as supported by Simpson et al. (2008). The rating conforms with the findings of Fabricatore et al. (2000) that the absence of difference in students' religiosity manifests that they do not vary in terms of their religious beliefs and practices.

Demographically speaking, it was found that men and women do not have religious differences, as Murphy (2016) supported. This also conforms with Musa (2015) that the students have high religious well-being regardless of whether they are male or female. On the one hand, the result of the current study affirms Rissler et al. (2014) that in terms of grade level, the religious well-being of the students showed no difference. Further, the study's findings corroborated with Madrigal et al. (2020) on the increasing significance of religion among adolescents, showing growth in recognizing religious beliefs and traditions as students' progress in grade levels. These findings encourage the public schools to recognize the value of religion in forming the religious well-being of the students, whether they are male or female (Musa, 2015).

The result also shows that the link between the students' religious faith and their family income was not significant. In other words, the student's family income has no impact in their religious beliefs and practices as supported by Joshi et al. (2009). Further, this does not support the claim of Crabtree (2010) that religiosity and spirituality are high among poor only. On the other hand, the no difference rating also signifies that there is no significant interaction between the students' religious affiliation and their religiosity, as supported by MacArthur (2008). Additionally, Kim and Seidlitz (2002) perceived that one's religiosity exists regardless of religious affiliation.

Given the findings, these imply the need for public schools to advance the essentials of religious and faith-related opportunities among their learners without referencing the demographics mentioned. When these opportunities are successfully advanced, the students' spiritual well-being, particularly their religious well-being, is also positively influenced along with their recognition of the essential values of life (King \& Boyatzis, 2015).

Table 5. Difference in the Degree of the Spiritual Well-Being in terms of Religious Well-being

\begin{tabular}{|c|c|c|c|c|c|}
\hline \multirow{2}{*}{ Variable } & \multicolumn{2}{|c|}{ Sex } & \multirow[t]{2}{*}{$\mathrm{U}$} & \multirow[t]{2}{*}{ z } & \multirow[t]{2}{*}{$\mathrm{p}$} \\
\hline & Male & Female & & & \\
\hline \multirow{14}{*}{ Religious Well-being } & 50.90 & 52.56 & 11556.000 & -1.792 & 0.073 \\
\hline & $(7.65)$ & $(6.82)$ & & & \\
\hline & \multicolumn{2}{|c|}{ Grade Level } & $\mathrm{U}$ & $\mathrm{z}$ & $\mathrm{p}$ \\
\hline & Grade 11 & Grade 12 & & & \\
\hline & 51.88 & 52.04 & 13192.500 & -0.461 & 0.645 \\
\hline & $(7.05)$ & $(7.36)$ & & & \\
\hline & \multicolumn{2}{|c|}{ Family Income } & $\mathrm{U}$ & $\mathrm{z}$ & $\mathrm{p}$ \\
\hline & Low-income class & High-income class & & & \\
\hline & 51.83 & 52.28 & 10499.000 & -0.575 & 0.565 \\
\hline & $(7.21)$ & $(7.09)$ & & & \\
\hline & \multicolumn{2}{|c|}{ Religious Orientation } & $\mathrm{U}$ & z & $\mathrm{p}$ \\
\hline & Catholic & Non-Catholic & & & \\
\hline & 51.85 & 52.18 & 11181.000 & -0.184 & 0.854 \\
\hline & $(7.29)$ & $(6.88)$ & & & \\
\hline
\end{tabular}

Note: the difference is significant when $\mathrm{p} \leq 0.05$

\section{Difference in the Degree of the Spiritual Well-Being in terms of Existential Well-being}

Table 6 shows the difference in the degree of spiritual well-being in terms of existential wellbeing of senior high school students when grouped according to demographics. Utilizing Mann- 
Whitney $U$ Test, the findings showed no significant difference when grouped according to sex $[U=12054.500, p=0.229]$, grade level $[U=13181.500, p=0.637]$, family income $[U=9959.000, p=0.207]$, and religious orientation $[\mathrm{U}=10743.000, \mathrm{p}=0.463]$. Hence, the null hypothesis is accepted.

The no difference rating indicates that the demographics of students do not affect their spiritual well-being, particularly in terms of their existential well-being. This also reveals that the students have similar perceptions in terms of the way they perceive their meaning, purpose, or outlook in life, as supported by the study of Van Cappellen et al. (2016). This conforms with Bano (2014) that all human beings strive for this meaning and satisfaction in life. In other words, these public-school students share the exact search for purpose in life. However, generally speaking, because of the kind of values education and formation offered across all these educational institutions, the demographics do not influence the assessment (Lippman \& McIntosh, 2010). Hence, this implies encouragement among public schools to make use of the drive of these students in their search for meaning and satisfaction in life to inculcate them the necessary values in life. This also encourages further studies to validate the results of this study.

Particularly, regarding sex, the no difference supports Hendricks-Ferguson (2006) that this profile does not indicate a significant interaction with the existential well-being of the individual. This is also congruent with Yanez (2004), claiming no gender differences concerning a purpose in life. Meanwhile, when students are grouped according to grade level, this supports Alorani \& Alradaydeh (2018), arguing that there are no differences in the students' life satisfaction relative to academic level.

The result confirms its no connection with existential well-being in terms of income, as found in Diener (2009). This also supports the claim of Starks and Hughey (2003) that life satisfaction has nothing to do with their family income. On the contrary, this negates Poloma and Pendleton (1990), claiming that family income is the most important predictor of having a sense of purpose and direction in life. Lastly, the result of the current study affirms that the individual's religious affiliation has nothing to do with their existential well-being (Diener, 2009). However, this is not supported by Poloma and Pendleton (1990), where religion is perceived as a predictor of general life satisfaction and overall happiness. Hence, considering the findings, further studies are needed to validate the results and claims of this study.

$\underline{\text { Table 6. Difference in the Degree of the Spiritual Well-Being in terms of Existential Well-being }}$

\begin{tabular}{|c|c|c|c|c|c|}
\hline \multirow{2}{*}{ Variable } & \multicolumn{2}{|c|}{ Sex } & \multirow[t]{2}{*}{$\mathrm{U}$} & \multirow[t]{2}{*}{$z$} & \multirow[t]{2}{*}{$\mathrm{p}$} \\
\hline & Male & Female & & & \\
\hline \multirow{13}{*}{$\begin{array}{l}\text { Existential } \\
\text { Well-being }\end{array}$} & 46.40 & 47.57 & 12054.500 & -1.202 & 0.229 \\
\hline & $(7.72)$ & $(7.43)$ & & & \\
\hline & \multicolumn{2}{|c|}{ Grade Level } & $\mathrm{U}$ & $\mathrm{z}$ & $\mathrm{p}$ \\
\hline & Grade 11 & Grade 12 & & & \\
\hline & $\begin{array}{l}47.04 \\
(7.36)\end{array}$ & $\begin{array}{l}47.28 \\
(7.84)\end{array}$ & 13181.500 & -0.472 & 0.637 \\
\hline & \multicolumn{2}{|c|}{ Family Income } & $\mathrm{U}$ & $z$ & $\mathrm{p}$ \\
\hline & Low-income class & High-income class & & & \\
\hline & 46.87 & 47.87 & 9959.000 & -1.263 & 0.207 \\
\hline & $(7.63)$ & $(7.32)$ & & & \\
\hline & \multicolumn{2}{|c|}{ Religious Orientation } & $\mathrm{U}$ & $z$ & $\mathrm{p}$ \\
\hline & Catholic & Non-Catholic & & & \\
\hline & 46.93 & 47.66 & 10743.000 & -0.734 & 0.463 \\
\hline & $(7.68)$ & $(7.21)$ & & & \\
\hline
\end{tabular}

Note: the difference is significant when $\mathrm{p} \leq 0.05$

Theoretically, it was posited in the theory of Spiritual Well-Being by Paloutzian and Ellison (1979) that spiritual well-being is perceived as a "personality attribute conceived of having one vertical dimension connoting one's perception of a relationship to God, and one horizontal dimension connoting one's perception of life's meaning, purpose, or satisfaction with one's existence." Yet the results strongly indicate that religiosity are not closely linked with spiritual well-being. With the no 
significant difference result between the degree of spiritual well-being in this study, it does not justify the veracity and claim of this theory given the weak relationship between religiosity and spirituality (Diener, 2009). Further, there is no connection between religiosity and life satisfaction (Mak et al., 2011). Considering the findings, these imply that these public schools should create and implement opportunities for students to find personal meaning in life, relationships and provide tools that will help increase the students' level of spirituality (Nasrollahi et al., 2020).

\subsection{Conclusion}

Considering the findings, these imply the need for public schools in Bacolod City, Philippines to strengthen their religious and values formation to establish a strong link between these two important dimensions in the lives of their senior high school students. When these two are excellently associated, their sense of faith, disposition, meaning, and satisfaction in life are addressed and ensured. Hence, their spiritual well-being is also guaranteed. With this, these schools are encouraged to provide varied and sustainable religious activities which can aid the students in the recognition of the essential values in life. Aside from this, giving premium to the teachers' competence is vital in successfully achieving the quality values instruction and integration which can effectively result to the sustainable link between these two dimensions.

The findings of this study served as empirical reference in proposing varied activities in successfully advancing the religious and existential well-being of students among these public schools. This intends to sustainably establish the linked dimensions to develop the students' spiritual well-being. Meanwhile, with the limitations of this study to the demographics mentioned, further studies are encouraged employing other variables which are not covered to validate the claims of this research. With the dearth of literature in the context of these educational institutions, these further researches can create more impact among these public schools not just in improving and strengthening their educational formation and teacher quality but above all the preparation of the students for life ahead.

\section{REFERENCES}

Aguas, J. J. S. (2019). Catholic education in the Philippines. Encyclopedia of Teacher Education, 1-7. https://doi. org/10.1007/978-981-13-1179-6_147-1

Agoncillo, R.L. (2015). Understanding Catholic youth religiosity in a developing country. In the International Conference on Language, Education, Humanities, and Innovation (pp.127-134). https://icsai.org/ procarch/1iclehi/1iclehi-47.pdf

Alorani, O. I., \& Alradaydeh, M. T. F. (2018). Spiritual well-being, perceived social support, and life satisfaction among university students. International Journal of Adolescence and Youth, 23(3), 291-298. https://doi.org/10 $.1080 / 02673843.2017 .1352522$

Alicea, S., \& Edwin, P. (2014). The relationship of family, church, school, peers, media, and Adventist culture to the religiosity of Adventist youth in Puerto Rico. Dissertations. 185. https://digitalcommons.andrews.edu/ dissertations $/ 185$

Bano, A. (2014). Impact of meaning in life on psychological well-being and stress among university students. Existenzanalyse, GLE-International/Wien, 21-25.

Banusing, R. O. \& Bual, J. M. (2020). The quality of Catholic education of diocesan schools in the Province of Antique. Philippine Social Science Journal, 3(2), 35-36. https://doi.org/10.52006/main.v3i2.150

Banusing, R. O., \& Bual, J. M. (2021). Appraising the quality of diocesan Catholic education in accordance with Philippine Catholic Schools Standards. Philippine Social Science Journal, 4(2), 80-89. https://doi. org/10.52006/main.v4i2.344

Bryant, A. N., Choi, J. Y., \& Yasuno, M. (2003). Understanding the religious and spiritual dimensions of students lives in the first year of university. Journal of University Student Development, 44, 723-746. https://doi. org/10.1353/csd.2003.0063

Bual, J., \& Madrigal, D. (2018). The quality of Catholic education in a diocesan school relative to the Philippine Catholic school standards. Philippine Social Science Journal, 1(1), 41-53. https://doi.org/10.52006/main. v1i1.11

Bullough Jr, R. V. (2011). Ethical and moral matters in teaching and teacher education. Teaching and Teacher Education, 27(1), 21-28. https://doi.org/10.1016/j.tate.2010.09.007

Chirico, F. (2016). Spiritual well-being in the 21st century: It's time to review the current WHO's health definition. Journal of Health and Social Sciences, 1(1), 11-16

Cohen-Zada, D., \& Sander, W. (2006). Private school choice: The effects of religion and religiosity. In annual meeting of the Western Economic Association International, San Diego, CA. 
Cornelio J. (2011). Being Catholic as reflexive spirituality: The case of religiously involved Filipino students. Asia Research Institute Working Paper No. 146, http://dx.doi.org/10.2139/ssrn.1743931

Crabtree, S. (2010). Religiosity is highest in the world's poorest nations. Gallup News, 31.

Deb, S., McGirr, K., \& Sun, J. (2016). Spirituality in Indian University students and its associations with socioeconomic status, religious background, social support, and mental health. Journal of religion and health, 55(5), 1623-1641. https://doi.org/10.1007/s10943-016-0207-x

Dein, S., Loewenthal, K., Lewis, C.A. \& Pargament, K. (2020). COVID-19, mental health and religion: An agenda for future research. Mental Health, Religion, and Culture, 23:1, 1-9, https://doi.org/10.1080/13674676.2020.1768725

Diener E. (2009) Subjective well-being. In Diener E. (eds) The science of well-being. Social Indicators Research Series, vol 37. Springer, Dordrecht. https://doi.org/10.1007/978-90-481-2350-6_2

Department of Education (DepEd). (2016). K to 12 basic education curriculum senior high school - academic strand. https://www.deped.gov.ph/wp-content/uploads/2019/01/Introduction-to-World-Religions-andBelief-Systems.pdf

Ene, I., \& Barna, I. (2015). Religious education and teachers' role in students' formation towards social integration. Procedia-Social and Behavioral Sciences, 180, 30-35. https://doi.org/10.1016/j.sbspro.2015.02.081

Fabricatore, A. N., Handal, P. J., \& Fenzel, L. M. (2000). Personal spirituality as a moderator of the relationship between stressors and subjective well-being. Journal of Psychology and Theology, 28(3), 221-228. https://doi. org/10.1177/009164710002800305

Gallagher, S. K., \& Newton, C. (2009). Defining spiritual growth: Congregations, community, and connectedness. Sociology of Religion, 70(3), 232-261. https://doi.org/10.1093/socrel/srp039

Hendricks-Ferguson, V. (2006). Relationships of age and gender to hope and spiritual well-being among adolescents with cancer. Journal of Pediatric Oncology Nursing, 23(4), 189-199. https://doi. org/10.1177/1043454206289757

Hook, J. N., Davis, D. E., Van Tongeren, D. R., Hill, P. C., Worthington Jr, E. L., Farrell, J. E., \& Dieke, P. (2015). Intellectual humility and forgiveness of religious leaders. The Journal of Positive Psychology, 10(6), 499-506. https://doi.org/10.1080/17439760.2015.1004554

Johnson, S. (2001). Christian spiritual formation in an age of "whatever". Review \& Expositor, 98(3), 309-331. https://doi.org/10.1177/003463730109800302

Jomuad, P. D., Antiquina, L. M. M., Cericos, E. U., Bacus, J. A., Vallejo, J. H., Dionio, B. B., \& Clarin, A. S. (2021). Teachers' workload in relation to burnout and work performance.

Joshi, P., Hardy, E., \& Hawkins, S. (2009). The role of religiosity in the lives of the low-income population: $A$ comprehensive review of the evidence. Washington, DC: US Department of Health and Human Services.

Kim, S., \& Esquivel, G. B. (2011). Adolescent spirituality and resilience: Theory, research, and educational practices. Psychology in the Schools, 48(7), 755-765. https://doi.org/10.1002/pits.20582

Kim, Y., \& Seidlitz, L. (2002). Spirituality moderates the effect of stress on emotional and physical adjustment. Personality and Individual Differences, 32(8), 1377-1390. https://doi.org/10.1016/S0191-8869 (01)00128-3

King, P. E., Boyatzis C. (2015). Religious and spiritual development in handbook of child psychology and developmental science: Socioemotional processes. 7th Edition. Vol. 3, eds. Lamb M. E. https://doi. org/10.1002/9781118963418.childpsy323

Kloet, J., \& Galen, L. W. (2011). Personality and social integration factors distinguishing non-religious from religious groups: The importance of controlling for attendance and demographics. Archive for the Psychology of Religion, 33(2), 205-228. https://doi.org/10.1163/157361211X570047

Kolzow, D. R. (2014). Leading from within: Building organizational leadership capacity.

Kotaiah, V. (2014) Role of teachers in the development of moral values. International Journal of English Language Literature and Translation Studies 1: 70-72

Krause, N., Pargament, K. I., \& Ironson, G. (2017). Spiritual struggles and health: Assessing the influence of socioeconomic status. Journal for the scientific study of religion, 56(3), 620- 636. https://doi.org/10.1111/ jssr.12364

Lau, P. S. (2006). Spirituality as a positive youth development constructs: Conceptual bases and implications for curriculum development. International Journal of Adolescent Medicine and Health, 18(3), 363-370. https:// doi.org/10.1515/IJMH.2006.18.3.363

Legada, E. L., Madrigal, D. V., \& Maravilla, M. W. M. (2020). Spiritual well-being and resiliency of the diocesan seminarians of Antique. Philippine Social Science Journal, 3(1), 53-69. https://doi.org/10.52006/main.v3i1.124

Leijssen, M. (2014). Existential well-being counseling. Emerging Practice in Focusing-Oriented Psychotherapy: Innovative theory and applications, 138-153.

Lituañas, C. R. A. (2007). An inquiry at the millennial youth spiritual identity: Experiences of DLSU students. In DLSU arts Congress (pp. 1-12).

Lippman, L. H., \& McIntosh, H. (2010). The demographics of spirituality and religiosity among youth: International and US Patterns. Child Trends Research Brief, 2010-21.

MacArthur, S. S. (2008). Adolescent religiosity, religious affiliation, and premarital predictors of marital quality and stability. Utah State University.

Madrigal, D. V., Erillo, R. P., \& Oracion, E. G. (2020). Religiosity and spiritual well-being of senior high school students of a Catholic college in the Philippines. Recoletos Multidisciplinary Research Journal, 8(1), 79-95. https://doi.org/10.13140/RG.2.2.23548.08321 
Madrigal, D., \& Oracion, E. (2018). Religiosity and spiritual well-being of students in a Philippine Catholic University. In Book of Abstracts of the 2018 PSS National Conference (p. 37).

Mak, M. C. K., Han, Y. M. Y., You, J., Jin, M., \& Bond, M. H. (2011). Building life satisfaction through attachment to mother and beliefs about the world: Social axioms as mediators in two cultural groups. Mental Health, Religion \& Culture, 14(3), 223-239. https://doi.org/10.1080/13674670903456455

Mata-McMahon, J. (2016). Reviewing the research in children's spirituality (2005-2015): Proposing a pluricultural approach. International Journal of Children's Spirituality, 21 (2), 140-151. https://doi.org/10.1080/136443 6X.2016.1186611

Miller, A. S., \& Stark, R. (2002). Gender and religiousness: Can socialization explanations be saved? American journal of sociology, 107(6), 1399-1423.

Moberg, D. O. (2002). Assessing and measuring spirituality: Confronting dilemmas of universal and particular evaluative criteria. Journal of Adult Development, 9(1), 47-60. https://doi.org/10.1023/A:1013877201375

Mostafazadeh, F., \& Asadzadeh, F. (2012). The spiritual health of midwifery students. Journal of Health and Care, $14(1), 0-0$.

Murphy, C. (2016). Women generally are more religious than men, but not everywhere. Pew Research Center.

Musa, A. (2015). Spiritual beliefs and practices, religiosity, and spiritual well-being among Jordanian Arab Muslim university students in Jordan. Journal of Spirituality in Mental Health, 17, 34-49. https://doi.org/10.1080/193 49637.2014.957609

Nazam, F., \& Husain, A. (2016). Exploring spiritual values among school children. International Journal of School and Cognitive Psychology 3(175), 2. https://doi.org/10.4172/2469-9837.1000175

Oberholster, F. R., Taylor V, J. W., \& Cruise, R. J. (2000). Spiritual well-being, faith maturity, and the organizational commitment of faculty in Christian colleges and universities. Journal of Research on Christian Education, 9(1), 31-60. https://doi.org/10.1080/10656210009484896

Oracion, E., \& Madrigal, D. (2019). Catholic identity and spiritual well-Being of students in a Philippine Catholic University. Recoletos Multidisciplinary Research Journal, 7(2), 47-60. https://doi.org/10.32871/rmrj1907.02.04

Ownsworth, T., \& Nash, K. (2015). Existential well-being and meaning-making in the context of primary brain tumor: Conceptualization and implications for intervention. Frontiers Oncology. 5:96. https://doi. org/10.3389/fonc.2015.00096

Paloutzian, R. F., \& Ellison, C. W. (1982). Loneliness, spiritual well-being, and the quality of life. Loneliness: $A$ sourcebook of current theory, Research, and Therapy, 1.

Paloutzian, R. F., \& Ellison, C. W. (1979). Spiritual well-being, loneliness, and perceived quality of life. In Symposium presented at the annual meeting of the American Psychological Association, New York.

Pham, T., \& Del Castillo, F. (2020). Understanding the spiritual well-being of the youth in the Philippines and Vietnam: An exploratory study. Asia Pacific Journal of Multidisciplinary Research, 8(2), 27-34.

Poloma, M. M., \& Pendleton, B. F. (1990). Religious domains and general well-being. Social Indicators Research, 22(3), 255-276.

Poor, H. J., Borji, M., Borji, M., \& Moslemi, A. (2016). The relationship between spiritual well-being and quality of life and optimism on the staff of Arak University of Medical Science. Health, Spirituality and Medical Ethnic, $3(2), 8-15$.

Rissler, L. J., Duncan, S. I., \& Caruso, N. M. (2014). The relative importance of religion and education on university students' views of evolution in the Deep South and state science standards across the United States. Evolution: Education and Outreach, 7(1), 1-17. https://doi.org/10.1186/s12052-014-0024-1

Rovers, M, \& Kocum, L. (2010). Development of a holistic model of spirituality. Journal of Spirituality in Mental Health, 12(1), 2-24. https://doi.org/10.1080/19349630903495475

Scheper, E. (2013). Comparing public and private schools.

Schieman, S. (2010). Socioeconomic status and beliefs about God's influence in everyday life. Sociology of Religion, 71(1), 25-51. https://doi.org/10.1093/socrel/srq004

Schippers, M. C., \& Ziegler, N. (2019). Life crafting as a way to find purpose and meaning in life. Frontiers in Psychology, 10, 2778. https://doi.org/10.3389/fpsyg.2019.02778

Shek, D. (2012). Spirituality as a positive youth development constructs: A conceptual review. The Scientific World Journal. 2012. 458953. https://doi.org/10.1100/2012/458953.

Simpson, D. B., Cloud, D. S., Newman, J. L., \& Fuqua, D. R. (2008). Sex and gender differences in religiousness and spirituality. Journal of Psychology and Theology, 36(1), 42-52. https://doi.org/10.1177/009164710803600104

Spesia, D. D. (2016). Forming Catholic school principals as leaders of the new evangelization. Journal of Catholic Education, 20 (1). http://dx.doi.org/10.15365/joce.2001112016

Starks, S. H., \& Hughey, A. W. (2003). African American women at midlife: The relationship between spirituality and life satisfaction. Affilia, 18(2), 133-147. https://doi.org/10.1177/0886109903018002004

Taliaferro, L.A., Rienzo, B.A., Pigg, R. M., Miller, M. D., \& Dodd, V.J., (2009). Spiritual well-being and suicidal ideation among college students. Journal of American College Health, 58, 83-90. https://doi.org/10.3200/ JACH.58.1.83-90

Thornberg, R. (2008). The lack of professional knowledge in values education. Teaching and Teacher Education, 24(7), 1791-1798. https://doi.org/10.1016/j.tate.2008.04.004 
Van Cappellen, P., Toth-Gauthier, M., Saroglou, V., \& Fredrickson, B. L. (2016). Religion and well-being: the mediating role of positive emotions. Journal of Happiness Studies, 17, 485-505. https://doi.org/10.1007/ s10902-014-9605-5

Wink, P., \& Dillon, M. (2002). Spiritual development across the adult life course: Findings from a longitudinal study. Journal of adult development, 9(1), 79-94. https://doi.org/10.1023/A:1013833419122

Woodward II, J. D. (2020). Spiritual formation in Christian higher education. The University of Findlay.

Yanez, A. P. (2004). Existential predictors of psychological well-being. University of Nevada, Las Vegas.

\section{Correspondence:}

JOEHALLY B. CENA*

hally.cena@deped.gov.ph

https://orcid.org/0000-0003-1979-0017

JOEL M. BUAL

joelmaguadbual@gmail.com

https://orcid.org/0000-0002-8734-4855

*Corresponding Author 